\title{
ДОСЛІДЖЕННЯ ІНУЛІНУ В АРТИШОКУ СУЦВІТТЯХ, ЗАГОТОВЛЕНИХ В УКРАЇНІ ТА ФРАНЦІЇ
}

Вступ. На сьогодні нараховується понад 12000 лікарських рослин, що являють собою біогенетично сформований комплекс біологічно активних речовин (БАР) і широко використовуються як у науковій, так і народній медицині. Серед них на значну увагу заслуговують рослини, що застосовуються як харчові продукти та одночасно містять великий комплекс біологічно активних речовин. До таких рослин належить артишок посівний (Cynara scolymus L.) родини айстрові (Asteraceae), який, завдяки наявності різних груп БАР, широко використовують як жовчогінний, гепатопротекторний, діуретичний, антисклеротичний, протизапальний, знеболювальний, гіпоглікемічний засіб. БАР артишоку представлені вуглеводами, гідроксикоричними кислотами, фрлавоноїдами, ефрірною олією тощо.

Мета дослідження - виявити і визначити кількісний вміст інуліну в артишоку суцвіттях, заготовлених в Україні та Франції.

Методи дослідження. Наявність інуліну в сировині, яку досліджували, підтверджували за допомогою реакції Моліша. Кількісний вміст інуліну в артишоку суцвіттях визначали спектрофотометричним (метод 1) і ГХ хромато-мас-спектрофотометричним (метод 2) методами.

Результати й обговорення. Поява темно-фріолетового забарвлення свідчила про наявність інуліну в обох зразках досліджуваної сировини. Було встановлено, що вміст суми фрруктозанів, визначений спектрофотометричним методом, у артишоку суцвіттях, заготовлених в Україні, становив 2,31 \%, а заготовлених у Франції - 2,77 \%. Вміст інуліну, визначений ГХ хромато-мас-спектрооротометричним методом, складав, відповідно, 119,30 та 147,60 мг/мл.

Висновки. За допомогою реакції Моліша в обох зразках артишоку суцвіть встановлено наявність інуліну. За допомогою спектрофротометричного і ГХ хромато-мас-спектрофотометричного методів аналізу в артишоку суцвіттях, заготовлених в Україні та Франції, визначено кількісний вміст інуліну, який склав у артишоку суцвіттях, заготовлених в Україні, 2,31% і 119,30 мг/мл відповідно, в артишоку суцвіттях, заготовлених у Франції, - 2,77 \% і 147,60 мг/мл відповідно. Одержані результати дозволяють вважати сировину артишоку українського та фрранцузького походження взаємозамінною для отримання біологічно активних субстанцій.

КЛЮЧОВІ СЛОВА: артишок посівний; інулін; спектрофотометрія; газова хроматографрія.

ВСТУП. На сьогодні нараховується понад 12000 лікарських рослин, що являють собою біогенетично сорормований комплекс біологічно активних речовин (БАР) і широко використовуються як у науковій, так і народній медицині. Серед них на значну увагу заслуговують рослини, що застосовуються як харчові продукти та одночасно містять великий комплекс біологічно активних речовин [4]. До таких рослин належить артишок посівний (Cynara scolymus L.) родини айстрові (Asteraceae), який, завдяки наявності різних груп БАР, широко використовують як жовчогінний, гепатопротекторний, діуретичний, антисклеротичний, протизапальний, знеболювальний, гіпоглі(с) А. І. Федосов, В. С. Кисличенко, О. М. Новосел, 2017. кемічний засіб [4]. БАР артишоку представлені вуглеводами, гідроксикоричними кислотами, орлавоноїдами, ефрірною олією тощо [4].

Протягом багатьох століть велику увагу приділяли застосуванню такого полісахариду, як інулін [3]. Він $€$ полідисперсним фрруктаном сумішшю олігомерів і полімерів фрруктози $[2,6]$.

Ферментація інуліну відбувається у товстій кишці, що сприяє збільшенню біфрідобактерій у ній, зниженню кількості токсичних метаболітів, холестерину, ліпопротеїнів низької щільності, кров'яного тиску, нормалізації глюкози та ліпідів у крові, метаболізму вуглеводів і ліпідів, поліпшенню абсорбції $\mathrm{Ca}^{2+}, \mathrm{Mg}^{2+}, \mathrm{Fe}^{2+}, \mathrm{PO}_{4}^{3-}[1,3]$. Інулін проявляє імуномодулюючу [5], гіпохолесте- 
ринемічну, гепатопротекторну дії [3, 9]; ефеективний при отруєнні радіонуклідами та важкими металами, стимулює ріст кісток і знижує ризик виникнення кісткових захворювань, нормалізує функціональну діяльність кишечника $[3,7,9]$. Деякі комплексні сполуки та похідні інуліну можна використовувати як замінники крові, ін'єкційні препарати для введення заліза тощо. Японські вчені створили інуліновмісні препарати, які застосовують для лікування СНІДу [1]. Встановлено, що інулін добре засвоюється хворими на цукровий діабет, навіть у великих дозах. При цьому він не впливає на рівень глюкози та інсуліну в крові [2]. Таку його здатність широко використовують у виробництві продуктів дієтичного харчування для діабетиків $[1,2]$. Завдяки низькій калорійності, інулін застосовують у дієтичному харчуванні хворих з порушенням обміну речовин, наприклад з надлишковою масою тіла, оскільки зменшення маси повинно бути природним і не порушувати метаболічних процесів в організмі $[2,9]$.

Крім того, інулін широко використовують у харчовій промисловості. Він має здатність до утворення $з$ водою кремоподібних гелів з жироподібною структурою, що дозволяє застосовувати його при виробництві продуктів зі зниженою жирністю. Також цей полісахарид широко застосовують у рецептурах молочних, кондитерських, хлібобулочних виробів як добавку, що покращує їх смакові та дієтичні властивості $[2,10]$.

Мета дослідження - виявити і визначити кількісний вміст інуліну в артишоку суцвіттях, заготовлених в Україні та Франції.

МЕТОДИ ДОСЛІДЖЕННЯ. Об'єкТОМ дОслідження слугували артишоку суцвіття, заготовлені в Україні та Франції.

Для встановлення наявності інуліну 1000 мг подрібненої сировини, яку досліджували, заливали 10 мл гарячої води та екстрагували протягом 20 хв на киплячій водяній бані. Водну витяжку охолоджували, фрільтрували та упарювали до сухого залишку, який використовували для проведення реакції Моліша - кислота сульфатна концентрована і розчин $\alpha$-нарттолу [12].

Кількісне визначення інуліну проводили спектросотометричним і ГX хромато-мас-спектрофотометричним методами.

Спектрофотометричне визначення. Близько 1000 мг (точна наважка) подрібненої сировини поміщали в колбу зі шліфром місткістю 250 мл, додавали 100 мл води, перемішували, зважували, приєднували до зворотного холодильника і кип'ятили на водяній бані протягом 30 хв. Колбу охолоджували, зважували, доводили до попередньої маси водою. Витяжку фрільтрували крізь паперовий фрільтр у мірну колбу місткістю 100 мл, промивали фрільтр водою та доводили об'єм розчину до позначки (розчин A).

50 мл розчину А поміщали в колбу місткістю 250 мл, додавали 150 мл 96 \% етанолу, перемішували протягом 5 Хв, охолоджували, фрільтрували крізь паперовий фрільтр. Осад на фрільтрі та стінках колби послідовно промивали 15 мл 96 \% етанолу, 10 мл ацетону, 15 мл етилацетату. До осаду на фрільтрі та стінках мірної колби додавали гарячу воду порціями по 25 мл 3 рази, по 10 мл 2 рази до розчинення осаду. Фільтрати збирали в мірну колбу місткістю 100 мл і доводили об'єм розчину водою до позначки (розчин Б).

5 мл розчину Б поміщали в мірну колбу місткістю 25 мл, додавали 5 мл 0,1 \% розчину резорцину, доводили об'єм розчину кислотою хлористоводневою концентрованою до 25 мл, нагрівали на водяній бані при температурі $(80 \pm 2)^{\circ} \mathrm{C}$ протягом 20 хв, охолоджували до кімнатної температури та визначали оптичну густину при довжині хвилі 485 нм.

Вміст суми фрруктозанів (X, \%) у сировині, в перерахунку на фрруктозу й абсолютно суху сировину, обчислювали за формулою:

$$
X=\frac{A \cdot 100 \cdot 100 \cdot 25 \cdot 100 \cdot 100}{475 \cdot 100 \cdot m \cdot 50 \cdot 1 \cdot(100-W)},
$$

де $A$ - оптична густина випробовуваного розчину; 475 - коефріцієнт питомого поглинання комплексу фрруктози з розчином резорцину; $\mathrm{m}$ маса наважки сировини, г; W-втрата в масі при висушуванні сировини, \% [8].

ГХ хромато-мас-спектрофотометричне визначення. Близько 500 мг (точна наважка) порошкової сировини обробляли розчином метанолу при температурі $80^{\circ} \mathrm{C}$ на ультразвуковій бані протягом 4 год. Потім пробу охолоджували до температури $60{ }^{\circ} \mathrm{C}$, змішували зі 100 мкл фрерменту "Fructozyme", витримували на ультразвуковій бані протягом 30 хв і визначали загальний вміст фрруктози. Паралельно одержували пробу без проведення фрерментативного гідролізу інуліну, визначаючи вміст вільної фрруктози. 3 літературних джерел відомо, що артишоку суцвіття містять сахарозу, при гідролізі якої також утворюється фрруктоза. Тому при обчислюванні вмісту інуліну було враховано вміст сахарози. Розрахунок кількісного вмісту інуліну (Х, мг/мл) проводили за різницею між загальним вмістом фрруктози після фрерментативного гідролізу та сумою вільної фруктози з фруктозою, яка утворилася після гідролізу сахарози, за фрормулою:

$$
X=\frac{A \cdot\left(F_{1}-F_{2}-F_{3}\right)}{P},
$$


де $\mathrm{F}_{1}$ - концентрація загальної фрруктози, мг/мл; $\mathrm{F}_{2}$ - концентрація вільної фрруктози, мг/мл; $\mathrm{F}_{3}$ концентрація фрруктози, що утворюється в результаті гідролізу сахарози, мг/мл $\left(\mathrm{F}_{3}=\mathrm{S} / \mathrm{B}\right.$, де $\mathrm{S}$ - концентрація сахарози, B - емпіричний фрактор конверсії фруктози відносно сахарози, який дорівнює 2,13); А- емпіричний фрактор конверсії фрруктози відносно інуліну, який дорівнює 1,03; P - маса наважки досліджуваної сировини, мг $[11,12]$.

РЕЗУЛЬТАТИЙОБГОВОРЕННЯ.У УезУЛЬтаті проведеної реакції Моліша спостерігали появу

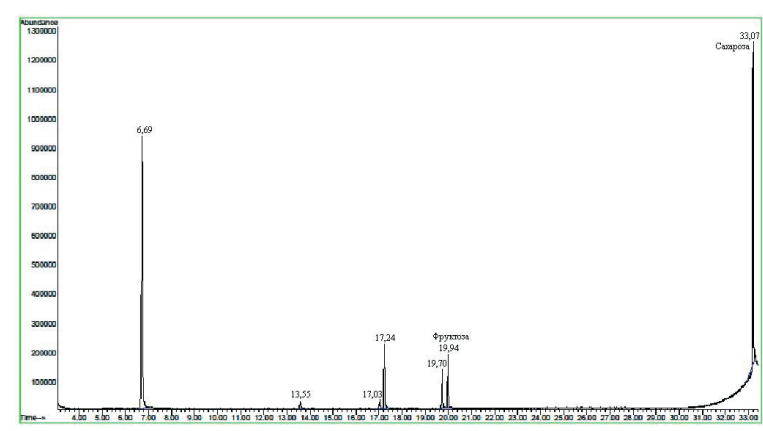

Рис. 1. Хроматограма визначення вільної фрруктози та сахарози в артишоку суцвіттях, заготовлених в Україні.

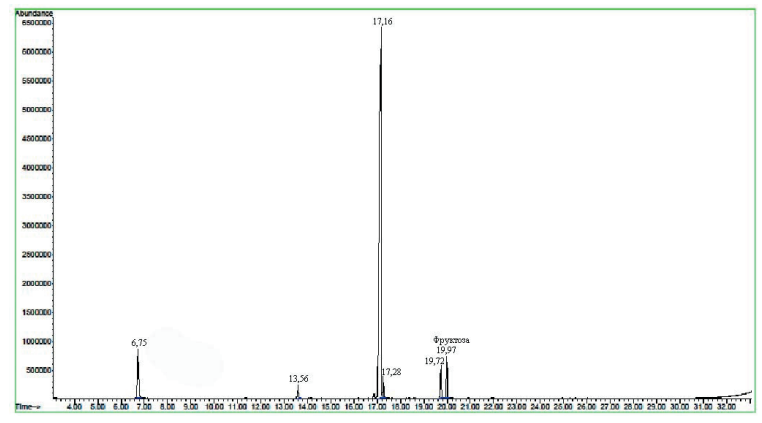

Рис. 2. Хроматограма визначення загального вмісту фрруктзи (після фрерментативного гідролізу) в артишоку суцвіттях, заготовлених в Україні. темно-фріолетового забарвлення, що свідчило про наявність інуліну в обох зразках досліджуваної сировини. Результати кількісного визначення інуліну в артишоку суцвіттях, заготовлених в Україні та Франції, наведено на рисунках 1-4 та в таблиці.

Як видно з таблиці, кількісний вміст інуліну, визначений спектрофотометричним методом, в артишоку суцвіттях, заготовлених в Україні, становив 2,31\%, ГХ хромато-мас-спектросоотометричним методом - 119,30 мг/мл. Вміст інуліну в артишоку суцвіттях, заготовлених у Франції, складав 2,77 \% та 147,60 мг/мл відповідно.

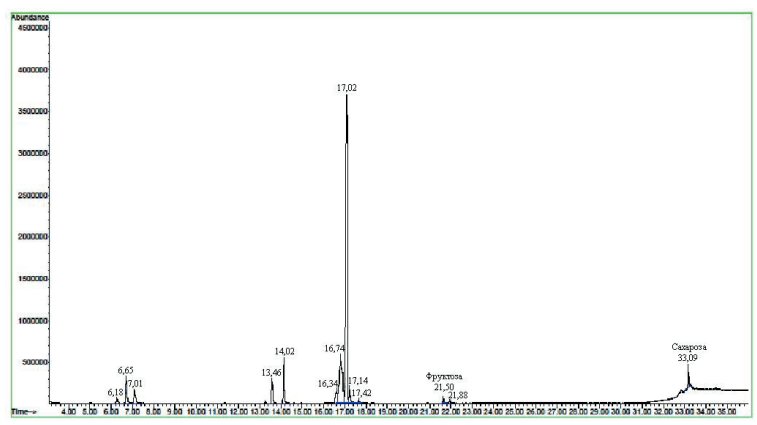

Рис. 3. Хроматограма визначення вільної фруктози та сахарози в артишоку суцвіттях, заготовлених у Франції.

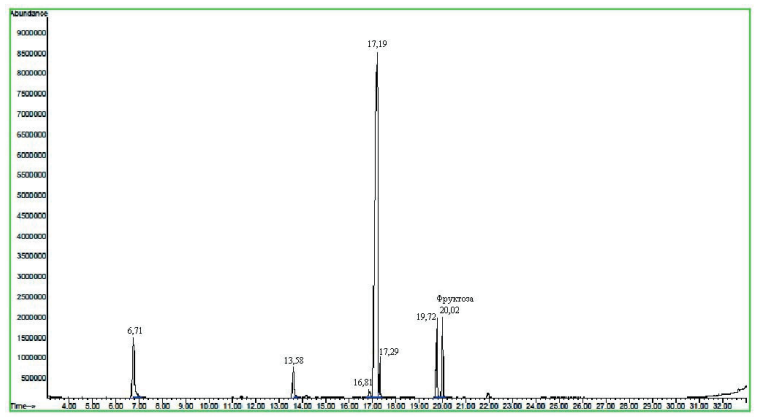

Рис. 4. Хроматограма визначення загального вмісту фрруктози (після фрерментативного гідролізу) в артишоку суцвіттях, заготовлених у Франції.

\section{Таблиця - Результати кількісного визначення інуліну в артишоку суцвіттях,}

заготовлених в Україні та Франції

\begin{tabular}{|c|c|c|}
\hline \multirow{2}{*}{$\begin{array}{c}\text { Назва сировини, } \\
\text { яку досліджували }\end{array}$} & \multicolumn{2}{|c|}{ Кількісний вміст, визначений методом } \\
\cline { 2 - 3 } & спектросротометрії & $\begin{array}{r}\text { ГХ хромато-мас- } \\
\text { спектросротометрії }\end{array}$ \\
\hline Артишоку суцвіття, заготовлені в Україні & $2,31 \pm 0,03 \%$ & 119,30 мг/мл \\
\hline Артишоку суцвіття, заготовлені у Франції & $2,77 \pm 0,04 \%$ & $147,60 \mathrm{мг/мл}$ \\
\hline
\end{tabular}

ВИСНОВКИ. 1. Задопомогою реакції Моліша в обох зразках артишоку суцвіть встановлено наявність інуліну.

2. За допомогою спектросротометричного і ГХ хромато-мас-спектрофотометричного методів аналізу в артишоку суцвіттях, заготовлених в Україні та Франції, визначено кількісний вміст інуліну, який склав у артишоку суцвіттях, заготовлених в Україні, 2,31 \% і 119,30 мг/мл відповідно, в артишоку суцвіттях, заготовлених у Франції, - 2,77 \% і 147,60 мг/мл відповідно.

3. Одержані результати дозволяють вважати сировину артишоку українського та фрранцузького походження взаємозамінною для отримання біологічно активних субстанцій. 


\section{СПИСОК ЛІТЕРАТУРИ}

1. Изменение инулина в клубнях топинамбура при хранении / М. Н. Назаренко, Т. В. Бархатова, М. А. Кожухова [и др.] // Науч. журн. КубГАУ. - 2013. № 94 (10). - С. 1-10.

2. Инулин из топинамбура: биосинтез, структура, свойства, применение / В. Н. Леонтьев, В.В.Титок, Д. А. Дубарь [и др.] // Труды БГУ. - 2014. - 9, ч. 1. C. $180-185$.

3. Ковтун Ю. А. Функціональні властивості інуліну / Ю. А. Ковтун, Т. О. Рашевська, О. А. Подковко // Актуальні задачі сучасних технологій : Міжнар. наук.техн. конф. молодих учених та студентів (Тернопіль, 11-12 груд. 2013 р.) : матеріали конфр. - Тернопіль, 2013. - C. 259-260.

4. Миррахимова Т. А. Артишок колючий-перспективное лекарственное растение / Т. А. Миррахимова, А. Н. Юнусходжаев. - Ташкент : ИПтД имени Чулпана, 2015. - 208 с.

5. Immunological Properties of Inulin-Type Fructans / L. Vogt, D. Meyer, G. Pullens [et al.] // Critical Reviews in Food Science and Nutrition. - 2015. - № 55. - P. 414436.

6. Inulin, a flexible oligosaccharide I: Review of its physicochemical characteristics / M. A. Mensink, H. W. Frijlink, K. van der Voort Maarschalk, W. L. J. Hinrichs // Carbohydrate Polymers. - 2015. - № 130. P. 405-419.

\section{REFERENCES}

1. Nazarenko, M.N., Barkhatova, T.V., Kozhukhova, M.A., Khripko, I.A., \& Burlakova, E.V. (2013). Izmenenie inulina $v$ klubniakh topinambura pri khranenii [Change of inulin in the tubers of Jerusalem artichoke at storage]. Nauchnyi zhurnal KubGAU. - Scientific Journal of Kuban State Agrarian University, 94 (10), 1-10 [in Russian].

2. Leontev, V.N., Titok, V.V., Dubar, D.A., Ignatovets, O.S., Lugin, V.G., Feskova, E.V. (2014). Inulin iz topinambura: biosintez, struktura, svoistva, primenenie [Inulin of Jerusalem artichoke: biosynthesis, structure, properties, application]. Trudy BGU. - Proceedings of the Belarusian State University, 9 (1), 180-185 [in Russian].

3. Kovtun, lu.A., Rashevska, T.O., \& Podkovko, O.A. (2013). Funktsionalni vlastyvosti inulinu [Inulin functional properties]. In Actual problems of modern technologies: Proceedings of the International scientific and technical conference of young researchers and students. (pp. 259260). Ternopil: TNTU [in Ukrainian].

4. Mirrakhimova, T.A., lunuskhodzhaev, A.N. (2015). Artishok koliuchii-perspektivnoe lekarstvennoe rastenie [Jerusalem artichoke - a prospective medicinal plant]. Tashkent: IPTD imeni Chulpana [in Russian].

5. Vogt, L., Meyer, D., Pullens, G., Faas, M., Smelt, M., Venema, K., Ramasamy, U., Schols, H.A., De Vos, P. (2015). Immunological Properties of Inulin-Type Fructans. Critical Reviews in Food Science and Nutrition, 55, 414-436.

6. Mensink, M.A., Frijlink, H.W., Van der Voort Maarschalk, K., Hinrichs, W.L.J. (2015). Inulin, a flexible
7. Inulin - a versatile polysaccharide with multiple pharmaceutical and food chemical uses / Th. Barclay, M. Ginic-Marcovic, P. Cooper, N. Petrovsky // J. Excipients and Food Chem. - 2010. - №1(3). - P. 27-50.

8. Kyslychenko V. S. The quantitative determination of fructosans in Echinacea pallida's roots / V. S. Kyslychenko, Ya. V. Dyakonova $/ / 7^{\text {th }}$ International Symposium on the Chemistry of Natural Compounds. - Tashkent, 2007. - P. 248

9. Miremadi F. Applications of inulin and probiotics in health and nutrition / F. Miremadi, N. P. Shah // International Food Research Journal. - 2012. - № 19 (4). P. 1337-1350.

10. Potential application of inulin in food industry; A review / M. Saeed, I. Yasmin, I. Pasha [et al.] // Pakistan Journal of Food Sciences. - 2015. - 25, Iss. 3. - P. 110 116.

11. Quantification of inulin content in selected accessions of Jerusalem Artichoke (Helianthus tuberosus L.) / J. Brkljaca, M. Bodroza-Solarov, J. Krulj [et al.] // Helia. 2014. - 37 (60). - P. 105-112.

12. Zarichanska O. Determination of inulin and free fructose content in modified roots of Hemerocallis species / O. Zarichanska, S. Marchyshyn, T. Yuschenko // $4^{\text {th }}$ International conference and workshop "Plant - the source of research material", Lublin (Poland), September 20-23, 2015. - P. 224.

oligosaccharide I: Review of its physicochemical characteristics. Carbohydrate Polymers, 130, 405-419.

7. Barclay, Th., Ginic-Marcovic, M., Cooper, P., Petrovsky, N. (2010). Inulin - a versatile polysaccharide with multiple pharmaceutical and food chemical uses. J. Excipients and Food Chem., 1 (3), 27-50.

8. Kyslychenko, V.S., Dyakonova, Ya.V. (2007). The quantitative determination of fructosans in Echinacea pallida's roots: Proceedings of the $7^{\text {th }}$ International Symposium on the Chemistry of Natural Compounds, Tashkent-Uzbekistan, October 16-18, 2007 (p. 248). Tashkent.

9. Miremadi, F., Shah, N. P. (2012). Applications of inulin and probiotics in health and nutrition. IFRJ, 19 (4), 1337-1350.

10. Saeed, M., Yasmin, I., Pasha, I., Randhawa, M.A., Khan, M.I., Shabbir, M.A., \& Khan, W.A. (2015). Potential application of inulin in food industry: A review. Pak. J. Food Sci., 25 (3), 110-116.

11. Brkljaca, J., Bodroza-Solarov, M., Krulj, J., Terzić, S., Mikić, A., Marjanović Jeromela, A. (2014). Quantification of inulin content in selected accessions of Jerusalem Artichoke (Helianthus tuberosus L.). Helia, 37 (60), 105-112.

12. Zarichanska, O., Marchyshyn, S., Yuschenko, T. (2015). Determination of inulin and free fructose content in modified roots of Hemerocallis species: Proceedings of the $4^{\text {th }}$ International conference and workshop "Plant the source of research material", Lublin (Poland), September 20-23, 2015 (p. 224). 


\section{ИССЛЕДОВАНИЕ ИНУЛИНА В АРТИШОКА СОЦВЕТИЯХ, ЗАГОТОВЛЕННЫХ В УКРАИНЕ И ФРАНЦИИ}

\section{Резюме}

Вступление. На сегодняшний день насчитывается более 12000 лекарственных растений, представляющих собой биогенетически сорормированный комплекс биологически активных веществ (БАВ) и широко используемых как в научной, так и народной медицине. Среди них особого внимания заслуживают растения, которые применяются в качестве пищевых продуктов и одновременно содержат большой комплекс биологически активных веществ. К таким растениям относится артишок посевной (Супага scolymus L.) семейства астровые (Asteraceae), который, благодаря наличию различных групп БАВ, широко используют как желчегонное, гепатопротекторное, диуретическое, антисклеротическое, противовоспалительное, анальгезирующее, гипогликемическое средство. БАВ артишока представлены углеводами, гидроксикоричными кислотами, срлавоноидами, эфирным маслом и др.

Цель исследования - обнаружить и определить количественное содержание инулина в артишока соцветиях, заготовленных в Украине и Франции.

Методы исследования. Инулин в исследуемом сырье обнаруживали с помощью реакции Молиша. Количественное содержание инулина в артишока соцветиях определяли спектрофотометрическим (метод 1) и ГХ хромато-масс-спектрофотометрическим (метод 2) методами.

Результаты и обсуждение. Появление темно-фриолетовой окраски свидетельствовало о наличии инулина в обоих образцах исследуемого сырья. Было установлено, что содержание суммы фрруктозанов, определенное спектрофротометрическим методом, в артишока соцветиях, заготовленных в Украине, составило 2,31 \%, а заготовленных во Франции - 2,77\%. Содержание инулина, определенное ГХ хроматомасс-спектрофотометрическим методом, составило, соответственно, 119,30 и 147,60 мг/мл.

Выводы. С помощью реакции Молиша в обоих образцах артишока соцветий установлено наличие инулина. С помощью спектрофротометрического и ГХ хромато-масс-спектрофротометрического методов анализа в артишока соцветиях, заготовленных в Украине и Франции, определено количественное содержание инулина, которое составило в артишока соцветиях, заготовленных в Украине, 2,31 \% и 119,30 мг/мл соответственно, в артишока соцветиях, заготовленных во Франции, - 2,77 \% и 147,60 мг/мл соответственно. Полученные результаты позволяют считать сырье артишока украинского и фрранцузского происхождения взаимозаменяемым для получения биологически активных субстанций.

КЛЮЧЕВЫЕ СЛОВА: артишок посевной; инулин; спектрофотометрия; газовая хроматография.

A. I. Fedosov, V. S. Kyslychenko, O. M. Novosel NATIONAL UNIVERSITY OF PHARMACY, KHARKIV

\section{THE STUDY OF INULIN IN ARTICHOKE INFLORSCENCES COLLECTED IN UKRAINE AND IN FRANCE}

\section{Summary}

Introduction. There are over 12000 medicinal plants encountered nowadays which are a biogenetically formed complex of biologically active compounds (BAC) and are extensively used in scientific as well as folk medicine. The plants which are used as food products and contain a large number of biologically active compounds are of great importance. Artichoke (Cynara scolymus L.) from Asteraceae family belongs to the group of plants which due to the presence of different groups of BAC is widely used as cholagogue, hepatoprotective, diuretic, antisclerotic, antiinflammatory, analgesic, hypoglycaemic agent. BAC of artichoke is represented by carbohydrates, hydroxycinnamic acids, flavonoids, essential oil etc.

The aim of the study - identification and determination of the quantitative content of inulin in the artichoke inflorescences collected in Ukraine and France.

Methods of the research. The presence of inulin in the studied plant material was confirmed using the Molisch's test. The quantitative content of inulin in the artichoke inflorescences was determined spectrophotometrically (method 1) and by the means of GC chromato-mass-spectrometric method (method 2). 
Results and Discussion. The appearance of the dark-violet coloring confirmed the presence of inulin in both samples of the studied plant material. The content of fructosanes' sum, determined spectrophotometrically, was found to be $2.31 \%$ in the artichoke inflorescences collected in Ukraine, and $2.77 \%$ in those collected in France. The content of inulin determined by the means of GC chromato-mass-spectrometry comprised $119.30 \mathrm{mg} / \mathrm{ml}$ and $147.60 \mathrm{mg} / \mathrm{ml}$ respectively.

Conclusions. The presence of inulin was confirmed using the Molisch's test in both samples of artichoke inflorescences. The content of inulin in the artichoke inflorescence collected in Ukraine and France was determined by the means of spectrophotometric and GC chromato-mass-spectrometric methods of analysis, and comprised $2.31 \%$ and $119.30 \mathrm{mg} / \mathrm{ml}$ respectively in the artichoke inflorescences collected in Ukraine, and $2.77 \%$ and $147.60 \mathrm{mg} / \mathrm{ml}$ respectively in the artichoke inflorescences collected in France. The obtained results allow considering the plant material of artichoke of Ukrainian and French origin interchangeable for the biologically active substances obtaining.

KEY WORDS: artichoke; inulin; spectrophotometry; gas chromatography.

Отримано 27.01.17

Адреса для листування: А. І. Федосов, Національний фрармацевтичний університет, вул. Пушкінська, 53, Харків, 61002, Україна, e-mail: fedosov.a@ukr.net. 